\title{
Fungal endophytes of Panicum maximum and Pennisetum purpureum: isolation, identification, and determination of antifungal potential
}

\author{
Natália da Costa Maia ${ }^{1}$, Patrícia Nirlane da Costa Souza², Bárbara Temponi Vilarino \\ Godinho', Silvino Intra Moreira ${ }^{3}$, Lucas Magalhães de Abreu ${ }^{4}$, Liana Jank ${ }^{5}$, \\ Patrícia Gomes Cardoso ${ }^{1 *}$
}

\footnotetext{
${ }^{1}$ Universidade Federal de Lavras, Departamento de Biologia, Lavras, MG, Brasil.

2 Universidade Federal dos Vales do Jequitinhonha e Mucuri, Janaúba, MG, Brasil.

${ }^{3}$ Universidade Federal de Lavras, Departamento de Fitopatologia, Lavras, MG, Brasil.

${ }^{4}$ Universidade Federal de Viçosa, Departamento de Fitopatologia, Viçosa, MG, Brasil.

${ }^{5}$ Embrapa Gado de Corte, Campo Grande, MS, Brasil.
}

\begin{abstract}
This study aimed to isolate and identify endophytic fungi from the forage grass $P$. maximum and evaluate their ability to inhibit the growth of plant pathogenic fungi. One sample from P. purpureum grass was also included. Surface disinfected stem fragments were used for endophytic fungal isolation. One hundred and twenty-six endophytic fungi were isolated, of which 118 were from $P$. maximum and eight from $P$. purpureum. Morphological characteristics and internal transcribed spacer (ITS) and 18S (NS) sequence comparisons identified most isolated endophytic fungi as belonging to the phylum Ascomycota, with Sarocladium being the dominant genus. The isolates were subjected to in vitro antagonism tests against pathogenic fungi, and 31 endophytic fungi inhibited the growth of Bipolaris maydis, Penicillium expansum, and Sclerotinia minor. The results expand our knowledge of the diversity of endophytes associated with tropical grasses and suggest that they may represent new sources of antifungal metabolites for biocontrol and biotechnological purposes.
\end{abstract}

Key Words: antagonism, grasses, molecular identification, plant pathogens, rDNA

\section{Introduction}

In Brazil, forage grasses are the main source of animal feed for dairy and beef cattle (Lima et al., 2010). $P$. maximum and $P$. purpureum are two grass species originating from tropical Africa (Ndemah et al., 2000; Dinardo et al., 2003; Braz et al., 2006). These are the main forage grasses used for pasture formation in Central and South America, since they have high nutritional value and high dry matter production potential (Dias and Alves, 2008; Lédo et al., 2008; Lima et al., 2010; Queiróz et al., 2014). Panicum maximum is well diffused among livestock farmers, being considered one of the most productive in the Brazilian livestock industry (Jank et al., 2008; 2011). Pennisetum purpureum is important as forage for silage because of its high growth rate and biomass production per area, with great efforts,

Received: September 16, 2017

Accepted: May 1, 2018

*Corresponding author: patricia@dbi.ufla.br

Copyright (c) 2018 Sociedade Brasileira de Zootecnia. This is an Open Access article distributed under the terms of the Creative Commons Attribution License (http://creativecommons.org/licenses/by/4.0/), which permits unrestricted use, distribution, and reproduction in any medium, provided the original work is properly cited. therefore, being devoted to determining its palatability and nutritional values as an alternative forage crop (Wang et al., 2002).

Plants are constantly involved in interactions with a wide range of microbial populations. Endophytic fungi inhabit plant organs at some stage in their life cycle and colonize internal tissues of plants without causing apparent damage to their host (Petrini, 1991). Endophytes constitute a valuable source of bioactive secondary metabolites (Naik et al., 2009), which may protect their host against pathogen, insect, or animal attacks, or even have direct or indirect effects on plant growth (Porras-Alfaro and Bayman, 2011). There have been very few studies on warm season grasses and the endophytes associated with them (Ghimire et al., 2011). In this study, we surveyed the endophytic fungi naturally occurring in stems of $P$. maximum and $P$. purpureum, collected from three different locations in Brazil, and evaluated their ability to inhibit the growth of plant pathogenic fungi. To test such possible outcome, antagonism bioassays (in vitro tests with two or more organisms placed against each other in contact or not) were set. The inhibition, in the context of this study, is the ability of one organism to partially or totally diminish the growth of the other. 


\section{Material and Methods}

Plant samples of eleven cultivars of $P$. maximum and one of $P$. purpureum were collected in August and September 2012, and January 2013. Sampling sites included three experimental fields located in the Brazilian states of Mato Grosso do Sul and Minas Gerais (Table 1). Healthy tillers were collected from each plant at $10-15 \mathrm{~cm}$ above the soil and transported to a laboratory in plastic bags for fungal isolation.

Tillers were washed under running tap water and cut into 5-7-cm fragments. Surface disinfection was done by treating the stem fragments thrice with sterile water for $1 \mathrm{~min}, 96 \%$ ethanol for $3 \mathrm{~min}, 5 \%$ sodium hypochlorite for $3 \mathrm{~min}$, and sterile water three times for $1 \mathrm{~min}$ each. Approximately $100 \mu \mathrm{L}$ of the last water wash was plated on PDA and incubated, as a sterilization control, followed by drying on sterile filter paper. Disinfected tissues were cut into $0.5-\mathrm{cm}$ fragments and plated on PDA plates containing cefotaxime $\left(250 \mu \mathrm{g} \cdot \mathrm{mL}^{-1}\right)$. Following an incubation at $25{ }^{\circ} \mathrm{C}$, plates were checked regularly and fungal colonies emerging from the margins of sectioned tissues were subcultured onto PDA. Purified isolates were stored long-term in sterile microtubes containing sterile water, and kept at $4{ }^{\circ} \mathrm{C}$.

Initial grouping of fungal isolates into morphotypes, and their identification to the genus level were based on colony appearance, mycelium color, and structures of conidiomata, conidiophore, and conidia (size, color,

Table 1 - Origin of samples of P. maximum and P. purpureum cultivars

\begin{tabular}{|c|c|}
\hline Location & Sample/Cultivar \\
\hline \multirow{9}{*}{$\begin{array}{l}\text { Embrapa Beef Cattle, } \\
\text { Campo Grande - MS }\end{array}$} & P. maximum cv. Mombaça \\
\hline & P. maximum cv. Tanzânia \\
\hline & P. maximum cv. Massai \\
\hline & P. maximum $\mathrm{cv}$. Aruana \\
\hline & P. maximum cv. Gatton \\
\hline & P. maximum cv. BRS Zuri \\
\hline & P. maximum cv. Milênio \\
\hline & P. maximum $\mathrm{cv}$. Colonião \\
\hline & P. maximum cv. Tobiatã \\
\hline \multirow{6}{*}{$\begin{array}{l}\text { Universidade Federal de Lavras } \\
\text { (UFLA)/Lavras - MG }\end{array}$} & P. maximum cv. Mombaça \\
\hline & P. maximum $\mathrm{cv}$. Vencedor \\
\hline & P. maximum cv. Tanzânia \\
\hline & P. maximum cv. Colonião \\
\hline & P. maximum cv. Makueni \\
\hline & P. maximum $\mathrm{cv}$. Massai \\
\hline \multirow{2}{*}{$\begin{array}{l}\text { Embrapa Dairy Cattle, } \\
\text { Juiz de Fora - MG }\end{array}$} & P. maximum cv. Tanzânia \\
\hline & $\begin{array}{l}\text { P. maximum cv. Mombaça } \\
\text { P. purpureum } \mathrm{cv} \text {. Mott }\end{array}$ \\
\hline
\end{tabular}

shape, ornamentation, etc.). Cultivation of non-sporulating cultures on malt-extract-agar (MEA) was done to promote sporulation (Guo et al., 1998).

Sequencing of the internal transcribed spacer (ITS) and part of the $18 \mathrm{~S}$ (NS) region of the rDNA was carried out for all isolates to support morphological identification and to identify non-sporulating fungi. Genomic DNA from pure cultures was extracted from the mycelial mat using a Mobio UltraClean ${ }^{\circledR}$ Microbial kit. Amplifications of ITS and $18 \mathrm{~S}$ (NS) were carried out in $30 \mu \mathrm{L}$ reactions containing $15 \mu \mathrm{L}$ Qiagen Taq PCR Master Mix kit, $12 \mu \mathrm{L}$ of $\mathrm{H}_{2} \mathrm{O}$, $1 \mu \mathrm{L}$ of each primer (10 pmol), and $1 \mu \mathrm{L}$ of genomic DNA at $10 \mathrm{ng} / \mu \mathrm{L}$. The internal transcribed spacer was amplified using primers ITS1 (TCCGTAGGTGAACCTGCGG) and ITS4 (TCCTCCGCTTATTGATATGC), with the reaction conditions as: $2 \mathrm{~min}$ at $95{ }^{\circ} \mathrm{C}$, followed by 35 cycles of 1 min denaturation at $95{ }^{\circ} \mathrm{C}, 1 \mathrm{~min}$ of primer annealing at $50{ }^{\circ} \mathrm{C}, 1 \mathrm{~min}$ of extension at $72{ }^{\circ} \mathrm{C}$, with a final elongation of $7 \mathrm{~min}$ at $72{ }^{\circ} \mathrm{C}$. The NS was amplified using NS1 (GTAGTCATATGCTTGTCTC) and NS6 (GCATCACAGACCTGTTATTGCCTC) primers, and the reaction conditions were as follows: $1 \mathrm{~min}$ for initial denaturation at $94{ }^{\circ} \mathrm{C}$, followed by 35 cycles of $35 \mathrm{~s}$ denaturation at $94{ }^{\circ} \mathrm{C}, 50 \mathrm{~s}$ of primer annealing at $55^{\circ} \mathrm{C}$, 2 min of extension at $72{ }^{\circ} \mathrm{C}$, with a final elongation of $6 \mathrm{~min}$ at $72{ }^{\circ} \mathrm{C}$. Amplifications were performed in a Programmable Thermal Controller-100, (MJ Research, Inc) thermocycler.

The PCR products were purified and sequenced by Macrogen. Consensus sequences were assembled using SeqAssem software and compared against the GenBank database through BLAST searches using the Mega 6 software (Tamura et al., 2013). The closest hit sequences were checked for their authenticity and used as references for molecular identification of endophytic isolates.

Isolates of seven plant pathogenic fungi, namely B. maydis, Aspergillus ochraceus, P. expansum, S. minor, Fusarium verticillioides, Pyricularia oryzae, and Colletotrichum graminicola, were used in the antagonism bioassays.

The endophytic fungi and plant pathogens were cultivated for seven days at $25{ }^{\circ} \mathrm{C}$ on PDA. Mycelial disks $(5 \mathrm{~mm})$ of each endophyte were transferred to one side of a PDA plate. After seven days of incubation, $5 \mathrm{~mm}$ mycelial disks of plant pathogens were inoculated onto opposite sides of the plates containing the endophytes. Control plates contained the pathogens inoculated without endophytes. After seven days of paired incubation at $25^{\circ} \mathrm{C}$, the percentage of growth inhibition of the pathogens was calculated in relation to the control (Fávaro et al., 2012). Tests were performed in triplicate. 
The bioassay was also performed on Petri dishes divided into two partitions to verify if those endophytic fungi that inhibited the growth of phytopathogenic fungi in the first test were producing bioactive volatile compounds instead of, or in addition to, compounds secreted in the culture medium (Strobel et al., 2011).

\section{Results}

We isolated 118 fungi from 11 P. maximum cultivars (17 samples) and eight isolates from $P$. purpureum (one sample). From samples collected in Campo Grande, 53 isolates were obtained, with 52 obtained from Lavras and 21 from Juiz de Fora.

Most isolates belonged to the Ascomycota, with only two members of the Basidiomycota (Meira sp. and Sporisorium sp.) being isolated from P. maximum. The most frequent species was Sarocladium sp. (65 isolates), followed by Ramichloridium sp. (13) (Figure 1). Seventeen other taxa were isolated in frequencies varying from one to five isolates (Figure 1). Four isolates could only be identified to the order level, Capnodiales and Hypocreales, while one ascomycete isolate was only identified to the phylum level. Five species were identified among the eight endophytes isolated from P. purpureum, Sarocladium sp. (four isolates), Acremonium sp., Cladosporium sp., Paraconiothyrium sp., and Sporisorium sp. (one isolate from each taxon).

Thirty endophytic isolates from $P$. maximum and one from $P$. purpureum reduced the growth of at least one of the three of pathogenic fungi included in the antagonism bioassay, B. maydis, P. expansum, and S. minor (Table 2). The remaining tested plant pathogens were not inhibited by the endophytic fungi.

Seven endophytic fungi inhibited the growth of $B$. maydis, including five isolates of Sarocladium, with values

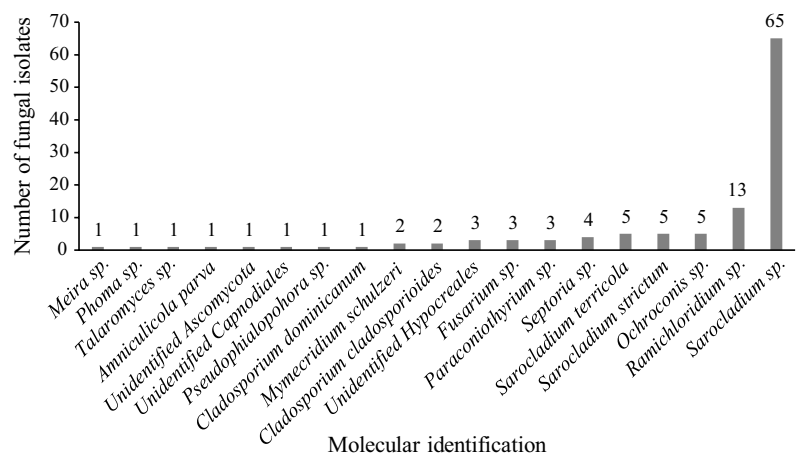

Figure 1 - Number of isolates of endophytic fungi from $P$. maximum. ranging from 22.41 to $60.87 \%$ of inhibition (Table 2). Twenty-seven out of the 31 tested isolates showed some antagonistic activity in vitro and inhibited the growth of S. minor. These isolates belonged to five different genera, with Sarocladium as the most common, reflecting the dominance of this genus in our survey. Growth reduction of $S$. minor ranged from 14.28 to $80.36 \%$ (Table 2).

One isolate of Ochroconis sp. from $P$. maximum (Milênio cultivar) inhibited the growth of $P$. expansum by $29.41 \%$. Two other Ochroconis isolates were active against S. minor (Table 2).

\section{Discussion}

The profile of fungal endophytes from $P$. maximum and $P$. purpureum followed the common patterns found in studies of tropical endophytes, in which only few taxa are dominant, and most are rare. Another common finding is the predominance of ascomycetes over basidiomycetes (Rodriguez et al., 2009; Marquéz et al., 2012).

Isolates of Sarocladium dominated the endophytic fungal assemblages in our present investigation. This genus was established in 1975 (Gams and Hawksworth, 1975); however, it was only recently delimited as a monophyletic group and shown to contain several species formerly classified in the morphogenus Acremonium (Summerbell et al., 2011; Giraldo et al., 2015). These findings highlight the common association of Sarocladium species with plants in the Poaceae family, including the rice sheet rot pathogen Sarocladium oryzae and the putative plant-protective endophytes Sarocladium zeae (formerly Acremonium zeae) from maize (Wicklow et al., 2008) and Sarocladium implicatum (formerly Acremonium implicatum) from Brachiaria brizantha (Kelemu et al., 2001). Two Sarocladium species were recently described from collections of grass endophytes, Sarocladium spinificis from Spinifex littoreus, a grass found on the Taiwanese coast (Yeh and Kirschner, 2014), and Sarocladium brachiariae, from B. brizantha grass, collected in China (Liu et al., 2017).

Reflecting the dominance of Sarocladium sp. among the isolated endophytes, most isolates capable of inhibiting the growth of $B$. maydis and $S$. minor belong to this genus. Chemical characterization of the isolates was not performed in this study, but the production of bioactive secondary metabolites in culture medium is highly likely. Dozens of metabolites are known from Sarocladium/ Acremonium, including the antibiotic helvolic acid and antifungal cerulenin, produced by $S$. oryzae (Bills et al., 2004), and antimicrobial pyrrocidines A and B, produced 
Table 2 - Antagonism test of P. maximum and P. purpureum endophytes against some phytopathogens

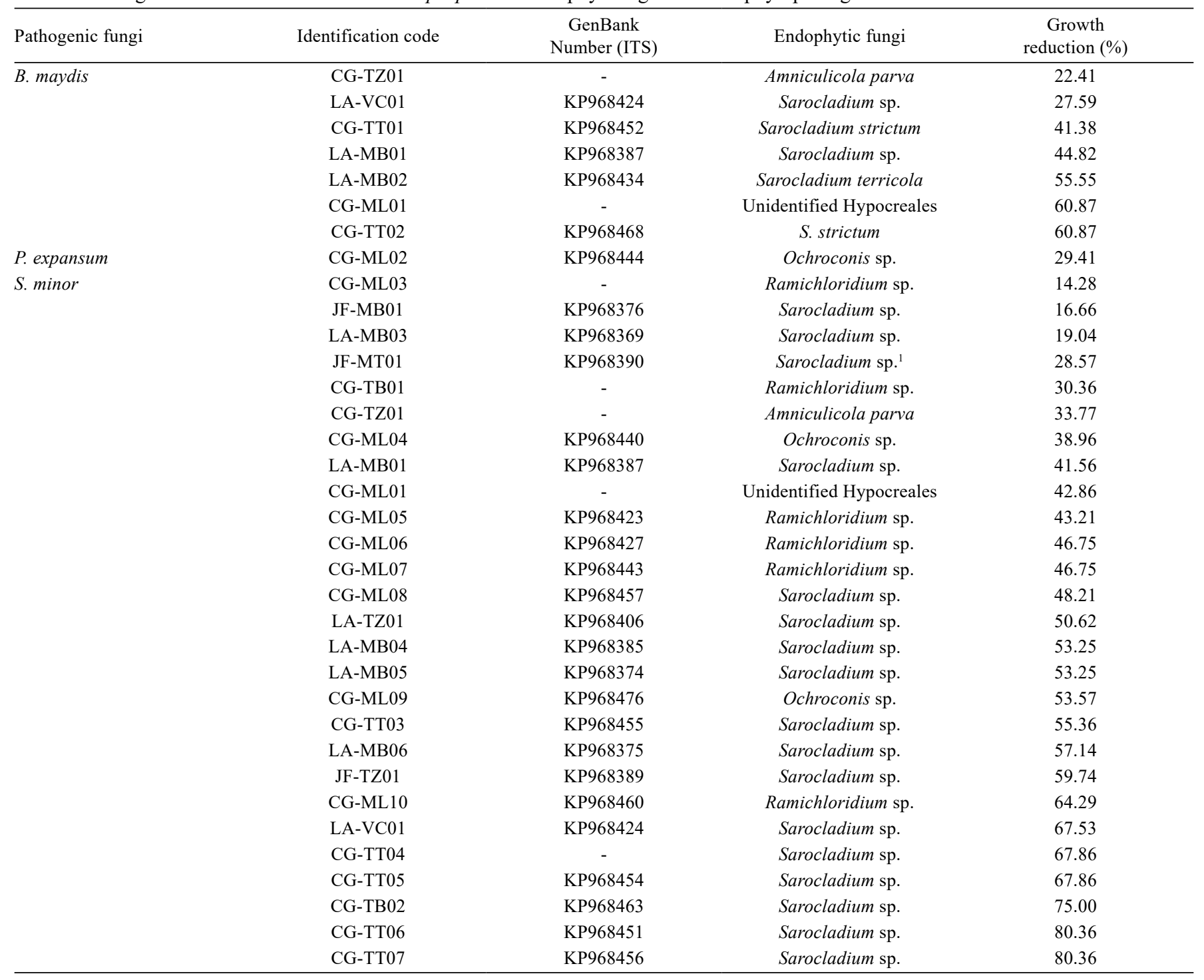

${ }^{1}$ Isolate from Pennisetum purpureum.

LA - Lavras, JF - Juiz de Fora, CG - Campo Grande; MB - Mombaça; VC - Vencedor; TZ - Tanzânia; TT - T65; ML - Milênio, TB - Tobiatã, MT - Mott.

by $S$. zeae (Wicklow et al., 2005). The putative protective action of $S$. zeae on maize ears against $F$. verticillioides and Aspergillus flavus was assigned to pyrrocidines, while a crude organic extract of a strain of $S$. oryzae, enriched in cerulenin content, was capable of reducing the severity of rice blast disease, caused by Pyricularia oryzae (Côrtes et al., 2014).

Thirteen endophytic isolates were assigned to Ramichloridium sp., making it the second most abundant taxon isolated in this study. Ramichloridium is a heterogeneous group of fungi including species with different lifestyles, such as saprobes and plant and human pathogens (Arzanlou et al., 2007). Several reports of endophytic Ramichloridium species are known mainly from dicotyledonous hosts, including Australian pine (Pinus nigra) (Jurc et al., 1996), Camellia (Camellia oleifera) (Zhou et al., 2013), and Artemisia (Artemisia аппиа) (Yuan et al., 2011).

\section{Conclusions}

To our knowledge, this is the first work with endophytes in $P$. maximum and $P$. purpureum grasses in Brazil, and contributes to the knowledge of fungal species associated with forage grasses in the country. Our results demonstrate the antifungal activities of Sarocladium and Ramichloridium isolates, the most common endophytes retrieved in our survey. This work will be expanded with additional in vitro and in vivo tests and by searching for compounds that are biosynthesized by selected fungal endophytes with potentially useful applications in biotechnology. 


\section{Acknowledgments}

We would like to thank the professors and researchers of the Universidade Federal de Lavras (UFLA), Embrapa Beef Cattle (Campo Grande-MS), and Embrapa Dairy Cattle (Juiz de Fora-MG), for providing the samples used in this work. The authors would like to thank the Fundação de Amparo à Pesquisa do Estado de Minas Gerais (FAPEMIG - CAG-APQ-02100-13), Coordenação de Aperfeiçoamento de Pessoal de Nível Superior (CAPES), and Conselho Nacional de Desenvolvimento Científico e Tecnológico (CNPq), for financial support and scholarships.

\section{References}

Arzanlou, M.; Groenewald, J. Z.; Gams, W.; Braun, U.; Shin, H.-D. and Crous, P. W. 2007. Phylogenetic and morphotaxonomic revision of Ramichloridium and allied genera. Studies in Mycology 58:57-93. https://doi.org/10.3114/sim.2007.58.03

Bills, G. F.; Platas, G. and Gams, W. 2004. Conspecificity of the cerulenin and helvolic acid producing 'Cephalosporium caerulens', and the hypocrealean fungus Sarocladium oryzae. Mycological Research 108:1291-1300. https://doi.org/10.1017/ S0953756204001297

Braz, A. J. B. P.; Procópio, S. O.; Cargnelutti Filho, A.; Silveira, P. M.; Kliemann, H. J.; Cobucci, T. and Braz, G. B. P. 2006. Emergência de plantas daninhas em lavouras de feijão e de trigo após o cultivo de espécies de cobertura de solo. Planta Daninha 24:621-628. https://doi.org/10.1590/S0100-83582006000400002

Côrtes, M. V.; Silva-Lobo, V. L.; Filippi, M. C.; Lima, D. and Prabhu, A. S. 2014. Potential for using crude extract of Sarocladium oryzae for suppression of rice blast. Tropical Plant Pathology 39:28-34. https://doi.org/10.1590/S1982-56762014000100004

Dias, M. C. L. L. and Alves, S. J. 2008. Avaliação da viabilidade de sementes de Panicum maximum Jacq pelo teste de tetrazólio. Revista Brasileira de Sementes 30:152-158. https://doi. org/10.1590/S0101-31222008000300020

Dinardo, W.; Toledo, R. E. B.; Alves, P. L. C. A. and Pitelli, R. A. 2003. Efeito da densidade de plantas de Panicum maximum Jacq. sobre o crescimento inicial de Eucalyptus grandis W. Hill ex Maiden. Scientia Forestalis 64:59-68.

Fávaro, L. C. L.; Sebastianes, F. L. S. and Araújo, W. L. 2012. Epicoccum nigrum P16, a sugarcane endophyte, produces antifungal compounds and induces root growth. PloS One 7(6):e36826. Available at: $<$ http://journals.plos.org/plosone/article?id=10.1371/ journal.pone.0036826>. Accessed on: Dec. 10, 2014.

Gams, W. and Hawksworth, D. L. 1975. Identity of Acrocylindrium oryzae Sawada and a similar fungus causing sheath-rot of rice. Kavaka 3:57-61.

Ghimire, S. R.; Charlton, N. D.; Bell, J. D.; Krishnamurthy, Y. L. and Craven, K. D. 2011. Biodiversity of fungal endophyte communities inhabiting switchgrass (Panicum virgatum L.) growing in the native tallgrass prairie of northern Oklahoma. Fungal Divers 47:19-27. https://doi.org/10.1007/s13225-010-0085-6

Giraldo, A.; Gené, J.; Sutton, D. A.; Madrid, H.; Hoog, G. S.; Cano, J.; Decock, C.; Crous, P. W. and Guarro, J. 2015. Phylogeny of Sarocladium (Hypocreales). Persoonia: Molecular Phylogeny and Evolution of Fungi 34:10-24. https://doi. org $/ 10.3767 / 003158515 \times 685364$
Guo, H.; Yang, H.; Mockler, T. C. and Lin, C. 1998. Regulation of flowering time by Arabidopsis photoreceptors. Science 279:1360-1363. https://doi.org/10.1126/science.279.5355.1360

Jank, L.; Resende, R. M. S. and Valle, C. B. 2008. Melhoramento genético de Panicum maximum. p.55-87. In: Melhoramento de forrageiras tropicais. Resende, R. M. S.; Valle, C. B. and Jank, L., eds. Embrapa, Campo Grande.

Jank, L.; Valle, C. B. and Resende, R. M. S. 2011. Breeding tropical forages. Crop Breeding and Applied Biotechnology 11(Special edition 1):27-34. https://doi.org/10.1590/S1984-70332011000500005

Jurc, M.; Jurc, D.; Gogala, N. and Simoncic, P. 1996. Air pollution and fungal endophytes in needles of Austrian pine. Phyton (Horn, Austria) 36:111-114.

Kelemu, S.; White Jr, J. F.; Muñoz, F. and Takayama, Y. 2001. An endophyte of the tropical forage grass Brachiaria brizantha: Isolating, identifying, and characterizing the fungus, and determining its antimycotic properties. Canadian Journal of Microbiology 47:55-62.

Lédo, F. J. D. S.; Pereira, A. V.; Souza Sobrinho, F. D.; Auad, A. M.; Jank, L. and Oliveira, J. S. E. 2008. Estimativas de repetibilidade para caracteres forrageiros em Panicum maximum. Ciência e Agrotecnologia 32:1299-1303. https://doi.org/10.1590/S141370542008000400040

Lima, E. S.; Silva, J. F. C.; Vásquez, H. M.; Andrade, E. N.; Deminicis, B. B.; Morais, J. P. G.; Costa, D. P. B. and Araújo, S. A. C. 2010. Características agronômicas e nutritivas das principais cultivares de capim-elefante do Brasil. Veterinária e Zootecnia 17:324-334.

Liu, X. B.; Guo, Z. K. and Huang, G. X. 2017. Sarocladium brachiariae sp. nov., an endophytic fungus isolated from Brachiaria brizantha. Mycosphere 8:827-834.

Márquez, S. S.; Bills, G. F.; Herrero, N. and Zabalgogeazcoa, Í. 2012. Non-systemic fungal endophytes of grasses. Fungal Ecology 5:289-297. https://doi.org/10.1016/j.funeco.2010.12.001

Naik, B. S.; Shashikala, J. and Krishnamurthy, Y. L. 2009. Study on the diversity of endophytic communities from rice (Oryza sativa L.) and their antagonistic activities in vitro. Microbiology Research 164:290-296. https://doi.org/10.1016/j.micres.2006.12.003

Ndemah, R.; Schulthess, F.; Poehling, M. and Borgemeister, C. 2000. Species composition and seasonal dynamics of Lepidopterous stem borers on maize and the elephant grass, Pennisetum purpureum (Moench) (Poaceae), at two forest margin sites in Cameroon. African Entomology 8:265-272.

Petrini, O. 1991. Fungal endophytes in tree leaves. p.179-197. In: Microbial ecology of leaves. Andrews, J. H. and Hirano, S. S., eds. Springer, New York.

Porras-Alfaro, A. and Bayman, P. 2011. Hidden fungi, emergent properties: endophytes and microbiomes. Annual Review of Phytopathology 49:291-315. https://doi.org/10.1146/annurevphyto-080508-081831

Queiróz, C. A.; Fernandes, C. D.; Verzignassi, J. R.; Valle, C. B.; Jank, L.; Mallmann, G. and Batista, M. V. 2014. Reação de acessos e cultivares de Brachiaria spp. e Panicum maximum à Pratylenchus brachyurus. Summa Phytopathologica 40:226-230. https://doi.org/10.1590/0100-5405/1899

Rodriguez, R. J.; White Jr, J. F.; Arnold, A. E. and Redman, A. R. A. 2009. Fungal endophytes: diversity and functional roles. New Phytologist 182:314-330. https://doi.org/10.1111/j.14698137.2009.02773.x

Strobel, G. A.; Dirske, E.; Sears, J. and Markworth, C. 2011. Volatile antimicrobials from Muscodor albus, a novel endophytic fungus. Microbiology 147:2943-2950. https://doi.org/10.1099/00221287$147-11-2943$

Summerbell, R. C.; Gueidan, C.; Schroers, H. J.; Hoog, G. S.; Starink, M.; Rosete, Y. A.; Guarro, J. and Scott, J. A. 2011. Acremonium phylogenetic overview and revision of Gliomastix, Sarocladium, 
and Trichothecium. Studies in Mycology 68:139-162. https://doi. org/10.3114/sim.2011.68.06

Tamura, K.; Stecher, G.; Peterson, D.; Filipski, A. and Kumar, S. 2013. MEGA6: molecular evolutionary genetics analysis version 6.0. Molecular Biology and Evolution 30:2725-2729. https://doi. org $/ 10.1093 / \mathrm{molbev} / \mathrm{mst} 197$

Wang, D.; Possw, J. A.; Donovan, T. J.; Shannon, M. C. and Lesch, S. M. 2002. Biophysical properties and biomass production of elephant grass under saline conditions. Journal of Arid Environments 52:447-456. https://doi.org/10.1006/jare.2002.1016

Wicklow, D. T.; Poling, S. M. and Summerbell, R. C. 2008. Occurrence of pyrrocidine and dihydroresorcylide production among Acremonium zeae populations from maize grown in different regions. Canadian Journal of Plant Pathology 30:425433. https://doi.org/10.1080/07060660809507540
Wicklow, D. T.; Roth, S.; Deyrup, S. T. and Gloer, J. B. 2005. A protective endophyte of maize: Acremonium zeae antibiotics inhibitory to Aspergillus flavus and Fusarium verticillioides. Mycological Research 109:610-618. https://doi.org/10.1017/ S0953756205002820

Yeh, Y. H. and Kirschner, R. 2014. Sarocladium spinificis, a new endophytic species from the coastal grass Spinifex littoreus in Taiwan. Botanical Studies 56:1-6. https://doi.org/10.1186/1999-3110-55-25

Yuan, Z. L.; Chen, Y. C. and Ma, X. J. 2011. Symbiotic fungi in roots of Artemisia annua with special reference to endophytic colonizers. Plant Biosystems 145:495-502. https://doi.org/10.108 $0 / 11263504.2010 .544863$

Zhou, S. L.; Yan, S. Z.; Wu, Z. Y. and Chen, S. L. 2013. Detection of endophytic fungi within foliar tissues of Camellia oleifera based on rDNA ITS sequences. Mycosystema 32:819-830. 